\title{
Pengaruh Rasio Profitabilitas dan Rasio Likuiditas terhadap Peringkat Sukuk Korporasi Perusahaan Periode 2015-2018
}

\author{
Ofi Maulidya Widyawati*, Nurhayati
}

Prodi Akuntansi, Fakultas Ilmu Ekonomi dan Bisnis, Universitas Islam

Bandung, Indonesia.

*ofymaulidya9@gmail.com, Nurhayati@unisba.ac.id

\begin{abstract}
This study aims to determine the effect of profitability ratios and liquidity ratios on sukuk ratings for the 2015-2018 period. The sukuk rating of a company can be seen from the performance performed by the company. To measure the company's performance in this study using profitability ratios and liquidity ratios. Profitability ratio is a ratio to measure the efficiency of a company and the company's ability to generate profits. While the liquidity ratio is a ratio to measure the company's ability to meet its short-term obligations. This research is included in a quantitative descriptive study with companies listed on the Indonesia Stock Exchange (IDX) and sukuk rating agencies in Indonesia (PEFINDO) as populations. The analysis technique used in this study is multiple regression analysis. The results of this study are that profitability ratios and liquidity ratios have a simultaneous effect on sukuk ratings, profitability ratios affect sukuk ratings, and liquidity ratios affect sukuk ratings. This can be seen from the results of the $t$ test which showed a sig value of $0.002<0.05$ and $0.000<0.05$.
\end{abstract}

Keywords: Profitability Ratio, Liquidity Ratio, and Sukuk Ranking

Abstrak. Penelitian ini bertujuan untuk mengetahui pengaruh rasio profitabilitas dan rasio likuiditas terhadap peringkat sukuk tahun periode 2015-2018. Peringkat sukuk suatu perusahaan dapat dilihat dari kinerja yang dilakukan oleh perusahaan. Untuk mengukur kinerja perusahaan tersebut pada penelitian ini menggunakan rasio profitabilitas dan rasio likuiditas. Rasio profitabilitas adalah rasio untuk mengukur efisiensi perusahaan dan kemampuan perusahaan dalam menghasilkan laba. Sedangkan rasio likuiditas adalaha rasio untuk mengukur kemampuan perusahaan dalam memenuhi kewajiban jangka pendeknya. Penelitian ini termasuk dalam penelitian deskriptif verifikatif dengan pendekatan kuantitatif dengan perusahaan yang terdaftar dalam Bursa Efek Indonesia (BEI) dan lembaga pemeringkat sukuk di Indonesia (PEFINDO) sebagai populasi. Teknik analisis yang digunakan dalam penelitian ini adalah analisis regresi berganda. Hasil dari penelitian ini adalah bahwa rasio profitabilitas dan rasio likuiditas berpengaruh secara simultan terhadap peringkat sukuk, rasio profitabilitas berpengaruh terhadap peringkat sukuk, dan rasio likuiditas berpengaruh terhadap peringkat sukuk. Ini dapat terlihat dari hasil uji t yang memperlihatkan nilai sig sebesar $0,002<0,05$ dan $0,000<0,05$.

Kata Kunci: Rasio Profitabilitas, Rasio Likuiditas, dan Peringkat Sukuk 


\section{A. Pendahuluan}

Obligasi syariah berkembang dengan sangat pesat di banyak negara di dunia akhir-akhir ini. Penerbitan obligasi syariah ini karena banyaknya masyarakat muslim di dunia yang ingin menginvestasikan uangnya dalam bentuk surat hutang akan tetapi mengingkan surat hutang tersebut diterbitkan sesuai dengan syariat-syariat islam. Salah satu faktor banyak negara di dunia yang mulai menerbitkan obligasi syariah melihat besarnya potensi yang akan diperoleh perusahaan dan investor. Dalam dunia internasional, obligasi syariah disebut dengan "Sukuk".

Dalam BahasacArab "Sukuk" memiliki arti yang mirip dengan sertifikat atau note. Obligasi konvensional sangat berbeda dengan Sukuk. Sukuk dapat dikatakan sebagai sertifikat investasi (bukti kepemilikan) atas surat asset berwujud atau hak manfaat (beneficial title) yang menjadi underlying assetnya. Akad yang digunakan dalam obligasi syariah adalah akad investasi. Namun dalam dunia investasi, sukuk yang ditebitkan setiap perusahaan pasti memiliki risiko gagal bayar (Default Risk).

Risiko gagal bayar merupakan resiko dimana investor tidak dapat memperoleh pembayaran dana yang dijanjikan oleh penerbit pada saat produk investasi jatuh tempo. Dengan adanya risiko gagal bayar ini maka para investor diharapkan lebih berhati-hati dalam memilih perusahaan untuk berinvestasi. Salah satu cara dalam melihat risiko gagal bayar suatu perusahaan adalah dengan melihat peringkat sukuk perusahaan tersebut.

Sari dalam Ratna (2017) mengungkapkan bahwa peringkat obligasi ini penting karena peringkat tersebut memberikan pernyataan yang informatif dan memberikan sinyal tentang probabilitas dan kegagalan untuk memenuhi kewajiban bagi suatu perusahaan. Semakin tinggi peringkat sukuk perusahaan maka kemungkinan risiko gagal bayar akan semakin kecil dan sebaliknya semakin rendah peringkat sukuk maka semakin tinggi risiko gagal bayar. Akan tetapi peringkat sukuk suatu perusahaan terkadang tidak mencerminkan kondisi keuangan suatu perusaahan.

Seperti yang diberitakan dalam www.kontan.com bahwa kinerja PT. Indosat mengalami penurunan disebabkan oleh anjloknya pendapatan sebesar Rp 6,6 triliun atau 22,68\%. Pendapatan Indosat pada 2018 mencapai Rp 23,14 triliun, sementara setahun sebelumnya tercatat Rp 29,93 triliun. Penurunan pendapatan terbesar pada lini bisnis seluler dari Rp 24,49 triliun menjadi Rp 18,03 triliun. Sementara lini bisnis multimedia, komunikasi data dan internet turun Rp 134,2 miliar menjadi Rp 4,38 triliun. Adapun pendapatan telepon tetap turun dari Rp 913 miliar menjadi Rp 729,3 miliar.

Data yang telihat diatas menunjukkan bahwa PT Indosat mengalami penurunan pendapatan sebesar 22,68\%, akan tetapi setelah mengalami penurunan pendapatan tersebut Pefindo tidak menurunkan rating PT. Indosat dimana PT Pemeringkat Efek Indonesia (Pefindo) memberikan peringkat idAAA (triple A) terhadap obligasi PT Indosat Tbk (ISAT) yakni Obligasi Berkelanjutan II Tahap III/2019 Seri A sebesar Rp 1,21 triliun (www.kontan.com). Yang bisa dikatakan bahwa tripel A merupakan peringkat sukuk tertinggi dan masuk di kategori investment grade yang mencerminkan kondisi keuangan suatu perusaahan dalam kondisi yang baik dan stabil.

Dengan adanya risiko gagal bayar dari suatu perusahaan maka para investor akan lebih berhati-hati ketika akan berinvestasi sukuk. Dengan adanya risiko gagal bayar dan juga fenomena yang terjadi peneliti membuat rumusan masalah berupa bagaimana pengaruh rasio profitabilitas dan rasio likuiditas terhadap peringkat sukuk korporasi perusahaan.

\section{B. Landasan Teori}

\section{Pengertian Sukuk}

Istilah sukuk berasal dari bentuk jamak dari bahasa Arab 'sak' atau sertifikat. Secara singkat, Accounting and Auditing Organisation for Islamic Financial Institution (AAOIFI) mendefinisikan "sukuk sebagai sertifikat bernilai sama yang merupakan bukti kepemilikan yang tidak dibagikan atas suatu aset, hak manfaat, dan jasa-jasa atau kepemilikan atas proyek atau kegiatan investasi tertentu". Prof. DR. Abdul Manan, SH., S.IP.,M.Hum, (2015:141) mendefinisikan Sukuk atau obligasi syariah sebagai surat berharga dalam instrumen investasi 
yang diterbitkan berdasar suatu transaksi atau akad syariah yang melandasinya (underlying transaction), yang dapat berupa ijarah (sewa), mudharabah (bagi hasil), musyarakah, atau yang lain. Maka dapat disimpulkan bahwa sukuk adalah sertifikat berbentuk surat berharga yang diterbitkan berdasarkan akad syariah yang merupakan bukti atas suatu asset atau hak manfaat.

Peringkat sukuk adalah suatu standarisasi yang diberikan oleh lembaga pemeringkat sukuk yang mencerminkan kemampuan penerbit sukuk dan kesediaan mereka untuk membayar pembayaran pokok tepat waktu. Ang dalam Hamidan (2017:74) berpendapat bahwa "Peringkat yang diberikan oleh pemeringkat sukuk akan menyatakan sukuk tersebut berada pada peringkat investment grade atau non investment grade". Investment grade merupakan tingkatan dimana peringkat sukuk disarankan untuk dibeli sedangkan non investment grade adalah tingkat sukuk dimana pemeringkat tidak menganjurkan untuk membeli sukuk tersebut. Skala peringkat yang terdapat pada PEFINDO di mulai dari AAA sampai dengan D secara umum terbagi menjadi dua kategori, yaitu investment grade (AAA, AA, A. BBB) dan non - investment grade (BB, B, CCC, D).

\section{Pengertian Rasio Profitabilitas}

John J. Hampton (2008:59) berpendapat bahwa "Rasio profitabilitas bertujuan mengukur efisiensi aktivitas perusahaan dan kemampuan perusahaan untuk memperoleh keuntungan". Sedangkan Lyn M. Fraser (2008:61) berpendapat bahwa, "Rasio profitabilitas, yaitu rasio untuk mengukur kinerja perusahaan secara keseluruhan dan efisiensi dalam pengelolaan aktiva, kewajiban, dan kekayaan".

\section{Pengertian Rasio Likuiditas}

Fred Weston dalam Kasmir (2016:110), menyebutkan bahwa rasio likuiditas (liquidity ratio) merupakan ratio yang menggambarkan kemampuan perusahaan memenuhi kewajiban (utang) jangka pendek. Artinya apabila perusahaan ditagih, maka akan mampu untuk memenuhi utang (membayar) tersebut terutama utang yang sudah jatuh tempo. Rasio likuiditas (liquidity ratio) digunakan untuk mengukur kemampuan perusahaan untuk memenuhi kewajiban jangka pendeknya. Rasio ini membandingkan kewajiban jangka pendek (atau lancar) yang tersedia untuk memenuhi kewajiban tersebut.

\section{Hipotesis}

Dalam menjalankan suatu kegiatan usaha sebuah perusahaan akan membutuhkan sejumlah dana yang nantinya akan digunakan untuk kegiatan operasional perusahaan. Dalam memperoleh sebuah dana, hal yang dilakukan oleh perusahaan adalah dengan mencari pinjaman kepada bank/pihak lain atau menerbitkan sebuah obligasi ataupun sukuk. Banyak perusahaan akan lebih memilih menerbitkan obligasi ataupun sukuk dari pada berhutang kepada bank atau pihak lain.

Accounting and Auditing Organisation for Islamic Financial Institution (AAOIFI) mendefinisikan "sukuk sebagai sertifikat bernilai sama yang merupakan bukti kepemilikan yang tidak dibagikan atas suatu aset, hak manfaat, dan jasa-jasa atau kepemilikan atas proyek atau kegiatan investasi tertentu". Dalam melakukan analisis laporan keuangan biasanya para analis akan melakukan perhitungan risiko yang mungkin terjadi di masa depan melalui rasio-rasio keuangan. Salah satu rasio yang sering dihitung atau dianalisis adalah rasio profitabilitas dan rasio likuiditas. Rasio profitabilitas sendiri bertujuan untuk mengukur efisiensi aktivitas perusahaan dan kemampuan perusahaan untuk memperoleh keuntungan. Sedangkan rasio likuiditas digunakan untuk mengukur kemampuan perusahaan untuk memenuhi kewajiban jangka pendeknya (Van Horne dan Wachowicz JR, 2005:205).

Suatu perusahaaan bisa dikatakan memiliki kinerja yang baik apabila perusahaan tersebut mampu menghasilkan sebuah laba yang tinggi dan juga dapat memenuhi kewajiaban jangka pendeknya tepat waktu. Dengan tingginya laba (profit) yang dihasilkan dan baiknya perusahaan dalam memenuhi kewajiaban jangka pendek oleh suatu perusaahan maka semakin tinggi pula peringkat sukuk yang di dapatkan oleh sebuah perusahaan. Dengan pemaparan hipotesis yang dilakukan penulis, maka penulis memunculkan hipotesis berupa:

$$
\mathrm{H}_{1}=\text { Rasio Profitabilitas berpengaruh terhadap Peringkat Sukuk }
$$


$\mathrm{H}_{2}=$ Rasio Likuiditas berpengaruh terhadap Peringkat Sukuk

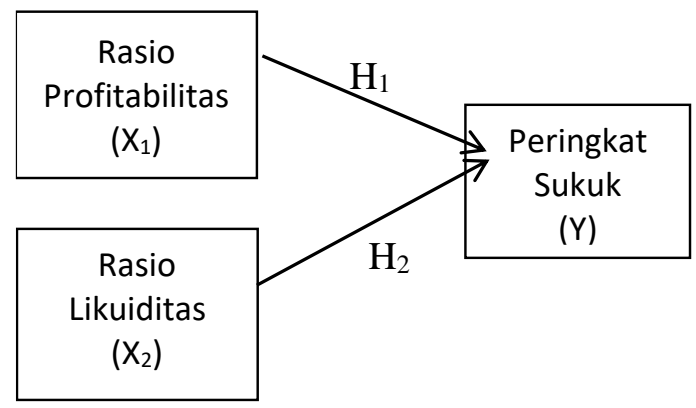

Gambar 1. Kerangka Pikir

\section{Hasil Penelitian dan Pembahasan}

\section{Uji Normalitas}

Tabel 1. Uji Normalitas

One-Sample Kolmogorov-Smirnov Test

\begin{tabular}{|ll|r|}
\hline & & $\begin{array}{r}\text { Unstandardiz } \\
\text { ed Residual }\end{array}$ \\
\hline $\mathrm{N}$ & Mean & 48 \\
Normal Parameters & a,b & Std. \\
& Deviation & .49383259 \\
Most Extreme & Absolute & .174 \\
Differences & Positive & .080 \\
& Negative & -.174 \\
Kolmogorov-Smirnov Z & 1.208 \\
Asymp. Sig. (2-tailed) & & .108 \\
\hline
\end{tabular}

Berdasarkan hasil uji normalitas dengan menggunakan Kolmogorov-Smirnov dapat dilihat nilai signifikansi sebesar 0,108. Maka, dapat disimpulkan bahwa data terdistribusi normal, dimana nilai sig lebih besar dari $0,05(0,108>0,05)$.

\section{Uji Multikolinieritas}

Tabel 2. Uji Multikolinearitas

\begin{tabular}{|c|c|c|c|}
\hline \multirow{2}{*}{\multicolumn{2}{|c|}{ Model }} & \multicolumn{2}{|c|}{$\begin{array}{c}\text { Collinearity } \\
\text { Statistics }\end{array}$} \\
\hline & & Tolerance & VIF \\
\hline \multirow{3}{*}{1} & (Constant) & & \\
\hline & ROA X1 & .825 & 1.212 \\
\hline & CR X2 & .825 & 1.212 \\
\hline
\end{tabular}


Berdasarkan hasil uji pada tabel dapat diketahui bahwa tidak terjadi multikolinieritas dalam penelitian ini. Hal ini dapat ditunjukkan dengan nilai VIF yang kurang dari 10 yaitu sebesar 1,212 untuk rasio profitabilitas dan rasio likuiditas $(1,212<10)$.

\section{Uji Heterokedastisitas}

Tabel 3. Uji Heterokedastisitas

\begin{tabular}{|rl|r|r|}
\hline \multicolumn{1}{|l|}{ Model } & \multicolumn{1}{c|}{$\mathrm{t}$} & \multicolumn{1}{c|}{ Sig. } \\
& & & \\
\hline \multirow{2}{*}{1} & (Constant) & 5.254 & .055 \\
& ROA X1 & -2.019 & .059 \\
& CR X2 & -1.238 & .222 \\
\hline
\end{tabular}

Pada tabel diatas dapat dilihat bahwa nilai signifikansi untuk variabel $\mathrm{X}_{1} \mathrm{ROA}$ yaitu sebesar $0,059 \geq 0,05$ dan nilai signifikasi variabel $X_{2}$ adalah sebesar $0,222 \geq 0,05$. Artiya bahwa tidak terjadi heterokedastisitas karena nilai signifikansi dari masing-masing variabel lebih besar dari 0,05 .

\section{Uji Autokorelasi}

Tabel 4. Uji Autokorelasi

\begin{tabular}{|l|r|}
\hline \multicolumn{2}{|c}{ Runs Test } \\
\hline & $\begin{array}{c}\text { Unstandardize } \\
\text { d Residual }\end{array}$ \\
\hline Test Value & a \\
Cases < Test Value & .12640 \\
Cases >= Test Value & 24 \\
Total Cases & 24 \\
Number of Runs & 48 \\
Z & 15 \\
Asymp. Sig. (2- & -2.772 \\
tailed) & .076 \\
Sumber: Data yang diolah
\end{tabular}

Hasil pengujian autokorelasi dengan menggunakan metode runs test pada tabel didapatkan nilai Asymp. Sig pada tabel sebesar 0,76 yang lebih besar dari nilai 0,05 (0,076> 0,05), maka dapat disimpulkan bahwa tidak ada autokorelasi.

\section{Analisis Regresi Linear Berganda}

Tabel 5. Tabel Uji Regresi Linear Berganda

\begin{tabular}{|cl|r|r|r|}
\hline \multicolumn{1}{|l|}{ Model } & \multicolumn{2}{|c|}{$\begin{array}{c}\text { Unstandardized } \\
\text { Coefficients }\end{array}$} & $\begin{array}{c}\text { Standardize } \\
\mathrm{d} \\
\text { Coefficients }\end{array}$ \\
\cline { 2 - 5 } & \multicolumn{1}{|c|}{ B } & Std. Error & \multicolumn{1}{c|}{ Beta } \\
\hline \multirow{2}{*}{1} & (Constant) & 5.426 & .131 & \\
& ROA X1 & 9.191 & 2.844 & .320 \\
& CR X2 & -1.062 & .173 & -.609 \\
\hline
\end{tabular}


$\mathrm{Y}=5,426+9,191 \mathrm{ROA}-1,062 \mathrm{CR}+\mathrm{e}$

Nilai konstant sebesar 5,426 menyatakan bahwa jika tidak ada kenaikan nilai dari variabel ROA dan CR, nilai variabel Y adalah 5,426.

Koefisien regresi variabel ROA sebesar 15,555 menyatakan bahwa setiap penambahan $($ karena tanda +) satu nilai pada variabel ROA akan memberikan kenaikan skor sebesar 15,555. Koefisien variabel ROA mempengaruhi secara signifikan terhadap variabel Y. Hal ini terlihat dari tingkat signifikansi variabel ROA sebesar 0,003 yang lebih kecil dari pada $0,05(0,003<$ $0,05)$.

Koefisien regresi variabel CR sebesar -2,104 menyatakan bahwa setiap penambahan (karena tanda - ) satu nilai pada variabel CR akan memberikan penurunan skor sebesar 2,104. Koefisien variabel CR mempengaruhi secara sigifikan terhadap variabel Y. Hal ini terlihat dari tingkat signifikansi variabel CR sebesar 0,000 yang lebih kecil daripada $0,05(0,000<0,05)$.

\section{Uji Simultan (Uji F)}

Tabel 6. Tabel Uji F

\begin{tabular}{|l|r|r|l|}
\hline Model & Sum of Squares & F & Sig. \\
\hline Regressio & 20.027 & 39.31 & $.000^{\mathrm{b}}$ \\
$\mathrm{n}$ & 11.462 & & \\
Residual & 31.489 & & \\
Total & & \\
\hline
\end{tabular}

Hasil berdasarkan tabel diatas dapat dilihat bahwa nilai sig 0,000 yaitu lebih kecil dari $0,05(0,000<0,05)$ artinya adalah rasio profitabilitas dan likuiditas secara simultan berpengaruh terhadap peringkat sukuk.

\section{Uji Parsial (Uji t)}

Tabel 7. Tabel Uji t

\begin{tabular}{|l|r|r|r|}
\hline Model & \multicolumn{1}{|c|}{$\begin{array}{c}\text { Standardized } \\
\text { Coefficients }\end{array}$} & $\mathrm{t}$ & Sig. \\
\cline { 2 - 3 } & \multicolumn{1}{|c|}{ Beta } & & \\
\hline \multirow{2}{*}{1 (Constant) } & & 41.507 & .000 \\
ROA X1 & .320 & 3.232 & .002 \\
CR X2 & -.609 & -6.147 & .000 \\
\hline
\end{tabular}

Pada tabel dapat dilihat bahwa nilai sig pada variabel X1 yaitu ROA bernilai 0,003 yaitu lebih kecil dari pada $0,05(0,003<0,05)$ yang memiliki arti bahwa ROA berpengaruh signifikan terhadap variabel $\mathrm{Y}$ yaitu peringkat sukuk. Untuk koefisien X2 yaitu CR memiliki sig sebesar 0,000 lebih kecil dari pada $0,05(0,000<0,05)$ yaitu bahwa variabel $\mathrm{X} 2$ yaitu CR berpengaruh secara signifikan terhadap variabel $\mathrm{Y}$ yaitu peringkat sukuk.

\section{Koefisien Determinasi}

Tabel 8. Tabel Koefisien Determinasi

\begin{tabular}{|l|c|r|r|r|}
\hline $\begin{array}{l}\text { Mode } \\
1\end{array}$ & $\mathrm{R}$ & $\begin{array}{c}\mathrm{R} \\
\text { Square }\end{array}$ & $\begin{array}{l}\text { Adjusted } \\
\mathrm{R} \text { Square }\end{array}$ & $\begin{array}{l}\text { Std. Error of } \\
\text { the Estimate }\end{array}$ \\
\hline 1 & $.797^{\mathrm{a}}$ & .636 & .620 & .504687 \\
\hline
\end{tabular}

Berdasarkan tabel diatas dapat dilihat bahwa nilai koefisien determinasi $\mathrm{R}^{2}$ sebesar 
0,620 sehingga dapat dikatakan bahwa hasil variabel dependen dalam penelitian ini yaitu peringkat sukuk dapat dipengaruhi sebesar $62 \%$ oleh variabel independen sisanya sebesar $38 \%$ dipengaruhi oleh faktor lain diluar model yang tidak diteliti dalam penelitian ini.

\section{Kesimpulan}

Hasil penelitian ini diharapkan dapat memberikan gambaran tentang pengaruh rasio profitabilitas dan rasio likuiditas terhadap peringkat sukuk. Berikut adalah beberapa kesimpulan yang dapat diambil, yaitu:

1. Berdasarkan hasil olah data menunjukan bahwa variabel profitabilitas berpengaruh terhadap peringkat sukuk, maka dapat disimpulkan bahwa hipotesis pertama yaitu terdapat pengaruh dari variabel profitabilitas terhadap peringkat sukuk, diterima. Semakin tinggi nilai return on asset, maka akan semakin tinggi pula perolehan peringkat sukuk.

2. Berdasarkan hasil olah data menunjukan bahwa variabel likuiditas berpengaruh terhadap peringkat sukuk, maka dapat disimpulkan bahwa hipotesis yaitu terdapat pengaruh dari variabel likuiditas terhadap peringkat sukuk, diterima. Karena, dengan semakin tingginya rasio likuiditas maka para manajer semakin memuaskan dalam memberdayakan current assetnya.

\section{Daftar Pustaka}

[1] Ayub. Muhammad. 2013. Understanding Islamic Finance. Jakarta: Gramedia Pustaka Utama.

[2] Bapepam LK dalam peraturan No.IX.A.14 Tentang Definisi Sukuk, tersedia di https://www.ojk.go.id/id/kanal/syariah/Pages/Pasar-Modal-Syariah.aspx

[3] Diamonalisa Sofianty \& Nunung Nurhayati 2018. Statistik Penelitian Dengan SPSS v. 17. 0

[4] Endah, Siti, dan Kartika. 2017. Pengaruh Rasio Likuiditas, Rasio Produktivitas, Rasio Profitabilitas, Dan Rasio Solvabilitas Terhadap Peringkat Sukuk. Jurnal Akuntansi dan Pajak, Vol. 18, NO. 01

[5] Fatwa Dewan Syari'ah Nasional Nomor 32/Dsn-Mui/Ix/2002 Tentang Obligasi Syari'ah, tersedia di https://tafsirq.com/fatwa/dsn-mui/obligasi-syariah

[6] Galih, Ratna, dan Erika. 2017. Pengaruh Profitabilitas, Ukuran Perusahaan, Produktivitas, Dan Reputasi Auditor Terhadap Peringkat Sukuk. Jurnal Ilmiah Wahana Akuntansi, Vol. 12, NO. 01 ISSN. 2302-1810.

[7] Ghozali, Imam. 2016. Aplikasi Analisis Multivariete Dengan Program IBM SPSS 23 (Edisi 8). Cetakan ke VIII. Semarang : Badan Penerbit Universitas Diponegoro.

[8] Hamida, Leily. 2017. Pengaruh Likuiditas Dan Leverage Terhadap Yield Sukuk Dengan Peringkat Sukuk Sebagai Variabel Intervening. Journal Ekonomi dan Bisnis, Vol.18.

[9] Huda, Nurul \& Heykal, Mohamad. 2010. Lembaga Keuangan Islam Tinjauan Teoritis dan Praktis. Jakarta: Prenada Media Group.

[10] Iyah, Faniah. 2018. Kepastian Hukum Sukuk Negara Sebagai Instrumen Investasi di Indonesia. Yogyakarta: Deepublish.

[11] Kasmir, DR. 2016. Pengantar Manajemen Keuangan: Edisi Kedua. Jakarta: Prenada Media Group.

[12] Kinerja Jeblok, Pefindo Tegaskan Rating IdAAA Buat Indosat, tersedia di https://www.cnbcindonesia.com/market/20190318140333-17-61331/kinerja-jeblokpefindo-tegaskan-rating-idaaa-buat-indosat (18/03/2019)

[13] Kriteria dan Peringkat Sukuk, tersedia di https://www.pefindo.com/

[14] Laporan Keuangan Perusahaan, tersedia di https://www.idx.co.id/

[15] Profil Perusahaan PT Indosat, tersedia di https://indosatooredoo.com/id/personal

[16] Profil Perusahaan PT Sumberdaya Sewatama, tersedia di https://sewatama.com/id/

[17] Profil Perusahaan PT XL Axiata, tersedia di https://www.xl.co.id/id 
8 | Ofi Maulidya Widyawati, et al.

[18] Manan, Abdul. 2015. Aspek Hukum Dalam Penyelenggaraan Investasi di Pasar Modal Syariah Indonesia. Jakarta: PT Fajar Interpratama Mandiri.

[19] Mardiyanto, Handono, 2009. Intisari Manajemen Keuangan. Jakarta : Grasindo.

[20] Pebruary, Silviana. 2016. Pengaruh Rasio Profitabilitas, Rasio Likuiditas, Rasio Leverage Dan Pendapatan Bunga Terhadap Rating Sukuk Korporasi Periode 2010-2013. Jurnal Dinamika Ekonomi \& Bisnis, Vol 13.

[21] Ratna, Astuti. 2017. Pengaruh Likuiditas, Produktivitas, Profitabilitas, Terhadap Peringkat Sukuk, Jurnal Ilmu Manajemen dan Akuntansi Terapan Vol. 8 No 1 p-ISSN. 2086-3748.

[22] Rahim \& Ahmad. 2016. Investigating FTSE KLCI Using CAAR Estimations Following Sukuk Announcement in Malaysia: Based on Sukuk Ratings. Journal of Investment and Management Vol. 5 ISSN. 2328-7721.

[23] Rodoni, Ahmad, 2009, Investasi Syariah, Lembaga Penelitian UIN, Jakarta.

[24] Sugiono, Arief \& Untung, Edy. 2008. Panduan Praktis Dasar Analisa Laporan Keuangan Pengetahuan Dasar bagi Mahasiswa dan Praktik Perbankan. Jakarta: Grasindo.

[25] Sutedi, Adrian. 2009. Aspek Hukum Obligasi dan Sukuk. Jakarta: Sinar Grafika.

[26] Sekaran, Uma dan Roger Bougie. 2016. Research Methods for Business. Edisi Ketujuh. United Kingdom: John Wiley \& Sons.

[27] Septi, Purwaningsih. 2013. Faktor Yang Mempengaruhi Rating Sukuk Yang Ditinjau Dari Faktor Akuntansi Dan Non-Akuntansi. Accounting Analysis Journal, Vol. 3 ISSN. 22526765.

[28] Safari, Ariff dan Mohamad. 2014. Sukuk Securities : New Ways of Debt Contracting. Singapore: John Wiley \& Sons.

[29] Sugiyono. (2017). Metode Penelitian Kuantitatif, Kualitatif, dan R\&D. Bandung : Alfabeta, CV.

[30] Taufik, Irfan, dan Rifki. 2016. The Less-Interrested Of Islamic Bank For Issuing Sukuk: Factors And Recommendations. Vol. 24

[31] Terbitkan Obligasi, Utang Indosat Numpuk \& DER Jadi 4,5 Kali, tersedia di https://www.cnbcindonesia.com/market/20190704173455-17-82793/terbitkan-obligasiutang-indosat-numpuk-der-jadi-45-kali (04/07/2019)

[32] Van Horne \& Wachowicz, JR. 2009. Prinsip-prinsip Manajemen Keuangan. Terjemahan Dewi Fitriasari, S.S., M.So., Ak. dan Deny Arnos Kwary, M. Hum. Jakarta: Salemba Empat.

[33] Winanti, Nurlaela \& Titisari. 2017. Pengaruh Rasiolikuiditas, Rasio Produktivitas, Rasio Profitabilitas, Dan Rasio Solvabilitas Terhadap Peringkat Sukuk. Jurnal Akuntansi dan Pajak, Vol. 18. 